Bangladesh J. Sci. Res. 28(2): 123-135, 2015 (December)

\title{
IMPACTS OF FLOOD ON CHAR LIVELIHOODS AND ITS ADAPTATION TECHNIQUES BY THE LOCAL PEOPLE
}

\author{
Md. Sirajul Islam*, Md. Solaiman, M. S. Islam, T. R. Tusher and M. H. Kabir \\ Department of Environmental Science and Resource Management, Mawlana Bhashani Science \\ and Technology University, Tangail-1902, Bangladesh
}

\begin{abstract}
The study showed that most of the farmers (81.81\%) in char area of flood lands were affected by flood as their crops were washed away by flood water as agricultural lands (59\%) were inundated in a high magnitude flood. During flood, almost 88.89\% farmers pass their days having no alternative occupation, and cannot afford to meet basic needs of their family as most of the Char lands were inundated for about two or three months, resulting in no crop production during that period. People reside in roads, schools and even on the top of the roof as there was no flood shelter in the study area. Besides these, rehabilitation programs were also not sufficient. It is also revealed that siltation over agricultural land reduces its fertility and productivity. To cope with this problem, people of Char land formulated and undertaken various adaptation techniques in their own way which varies depending on their socio-economic and environmental aspects, such as education, income, occupations and living conditions, as there was no organizational support. Finally, the study recommended that the policy makers and implementers along with non-governmental organizations should take their own responsibilities focusing the devastating situation of the previous flood in the study area. Also, the farmers should grow the flood tolerant varieties of crops in the area to mitigate loss of production and to lead a sustainable life.
\end{abstract}

Key words: Char land, flood, adaptation techniques

\section{Introduction}

Bangladesh is a flood plain country with an area of about $147,570 \mathrm{sq} . \mathrm{km} ; 6.7 \%$ of which consist of rivers and island water bodies (Ahmed 2001). Due to its unique natural settings, Bangladesh is most vulnerable to several natural hazards and every year natural calamities upset people's lives in some part of the country (UNEP 2001). Flood is the most common of them and some 30 to $35 \%$ of the total land surface of the country is flooded every year during monsoon season (Milliman et al. 1989). People from all classes including poor, middle class and rich face difficulties in leading their normal life during and after a devastating flood. Normal floods are seen as a blessing because they bring economic and environmental benefits by making arable land fertile and leading to an augmentation of agricultural production, while high magnitude floods are viewed as disastrous as they inundate large areas and cause widespread damage to crops, livestock and property as well as devastation to life and livelihoods (Blaikie et al. 1994, Smith 1996, Handmer et al. 1999, Paul 1984 and 1997, Brammer 1990, Rasid 1993, Few 2003).

*Author for correspondence: <islammstazu@yahoo.com>. 
The magnitude of the floods depend upon a number of factors like intensity and duration of rainfall, ground conditions, drainage characteristics, siltation of river-bed, erosion of banks, and human settlements in flood plains and on river banks.

The Char lands as well as reverine islands are areas of new land formed through the continuous process of erosion and deposition in the major rivers and coastal areas. Char lands of Bangladesh can be divided into five sub-areas such as the Jamuna, the Ganges, the Padma, the upper Meghna and the lower Meghna River. The old Brahmaputra and Tista also constitute some Char land areas (Islam et al. 2012). Individual and household movement is high, and temporary or permanent displacement is common in such areas. People face structuring access to productive land and their other resources are also highly vulnerable. Communities are largely excluded from mainland services and do not represent a priority for mainland leased government administration. Thus, a lack of social services perpetuates poor health, educational status particularly for women and children. The Char dwellers are the poorest and most vulnerable people to flooding and river bank erosion. The whole of the Char land is unstable and prone to annual and seasonal flooding. However, high-magnitude events cause severe loss and complete destruction. There were severe floods in 1987, 1988, and 1998 and recently in 2004 and 2007. In 1987 and 1988, less than 10\% of the Char area was above water during peak flood. About $50 \%$ of the Char land was flooded in 1991 (Islam et al. 2012). These multiple vulnerabilities are the underlying cause of chronic and persistent poverty on the Chars.

The Char people use their indigenous knowledge and techniques to cope with such diverse situation. So it is important to indicate and improve the indigenous knowledge to adapt with the Char environment. Adaptation or preventive measures can be taken before the event while mitigative or corrective measures can be taken during and after the event. Various structural (embankment, levee, polder, etc.) and non-structural (awareness raising, warning system, etc.) measures have been taken for flood prevention and mitigation. In recent years, it becomes evident that structural measures are neither economically viable, requiring extensive financial investment, nor environmentally friendly (Islam et al. 2012). Thus, local adaptation techniques are more viable and need to be increased to cope with flooding and river bank erosion. The objectives of the study were to find out the impacts of flood on Char livelihood, and also to assess the indigenous adaptation techniques against such natural hazards. The findings of the study will reveal how the Char people adapt themselves with flood, and will also find out the causes addressing the adaptation techniques of the Char people in different sectors of their livelihood. The findings can help the government and the other organizations to take proper steps for improving the livelihood of the Char people.

\section{Materials and Methods}

The study was conducted in three Char land villages of Muradpur, Ghorjan and South Teguri of Ghorjan union in Chauhali Upazila, Sirajgonj district, Bangladesh. The study area was located at the south-western part of the Chauhali Upazila (Fig. 1). Three villages are situated in the womb of 
the Jamuna river are flooded frequently in every year. The people of these Chars were friendly and majority of the households are either directly or indirectly dependent on agriculture for their livelihoods.

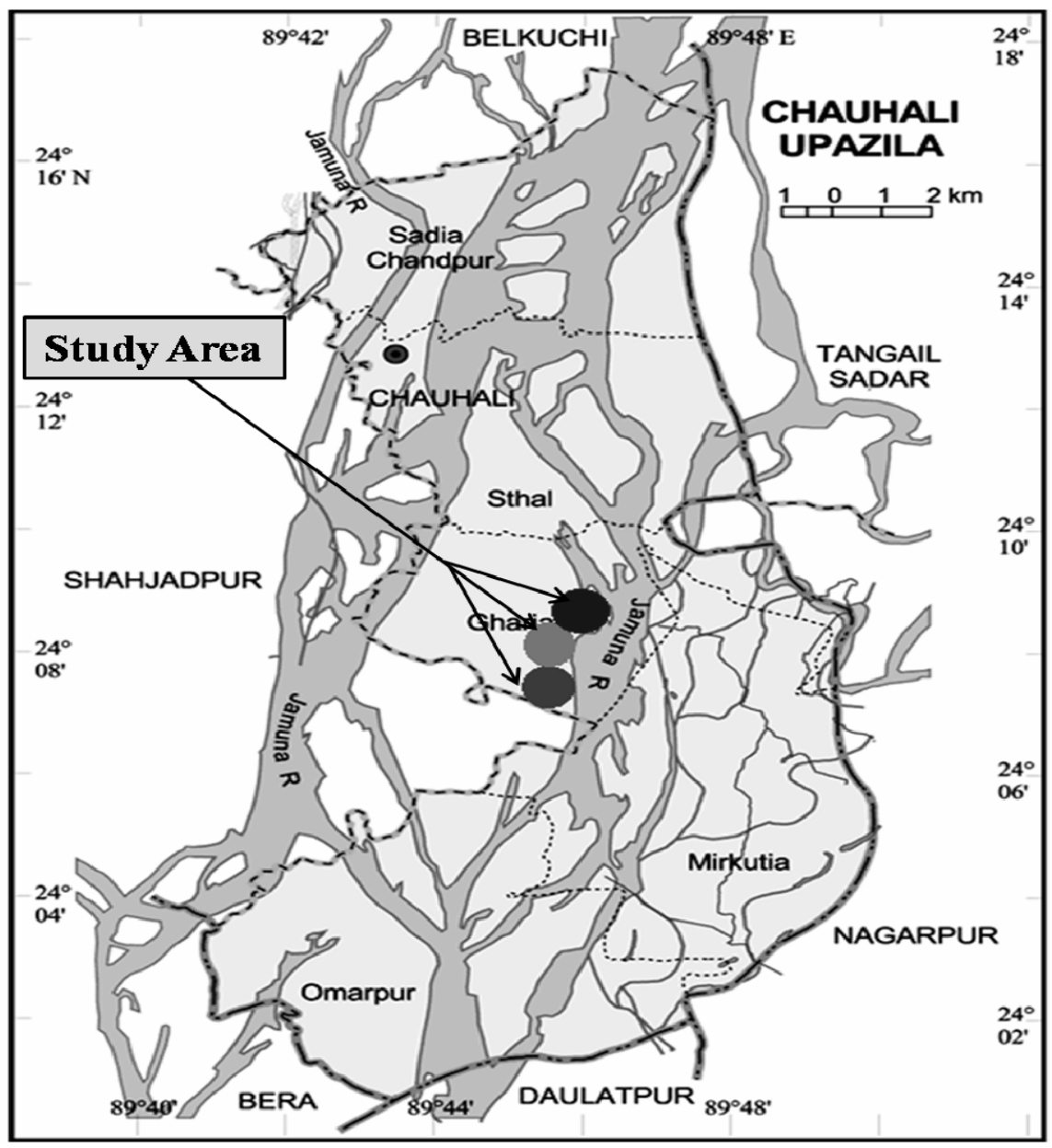

Fig. 1. Map showing the study area of Chauhali Upazila in Sirajgonj district, Bangladesh (Source: Banglapedia 2008).

The study was primarily based on data collected from three Char land villages through field observation, interviews and questionnaire survey during the period from January to June, 2012. The primary data were collected through interviews with key informants in Muradpur, Ghorjan and South Teguri Chars, household surveys and unstructured interviews as well as via focus group discussions with household members from three villages. The total households in Muradpur, Ghorjan and South Teguri Char were 175, 200 and 189, respectively. Key informants were selected purposively while simple random sampling was used to identify households. A total of 
100 households were selected from each village for data collection. There are many kinds of secondary data like the area of study, population of the area, cultivable land of the area, previous data on flooding, collected from the Union Parishad Office, Upazila Land Office, NGOs, Bangladesh Disasters Preparedness Center (BDPC), Bangladesh Water Development Board (BWDB), etc. The collected data were, then, analyzed by using Statistical Package for Social Sciences (SPSS 12.0) and Microsoft Office Excel.

\section{Results and Discussions}

Flood characteristics such as height of floodwater, frequency, duration of flooding, etc., influence people's adaptation strategies. A longer period of flooding has more severe ramifications than floodwater height. If floodwater remains stagnant for a long time in a locality, the level of total damage rises and hence people's ability to cope with the situation decreases. Similarly, pollution increases if water remains stagnant for a long time and adapting strategies fail in relation to health issues. It is also evident in the study that if floodwater remains stagnant for a long time, it causes a disruption to people's food and drinking water supply, reducing the ability to cope with and augmenting vulnerability. Thus, there is a direct link between the effectiveness of adapting strategies and the nature of flooding and people's socioeconomic conditions, with lower-income people being the most vulnerable.

Most of the respondents (70\%) of all classes are affected by flood in the study area (Fig. 2). The most vulnerable people are farmers, agricultural labors, fishermen, boatmen and people involved with small business. Flood causes death and injuries to people and people become homeless, landless and suffer from starvation.

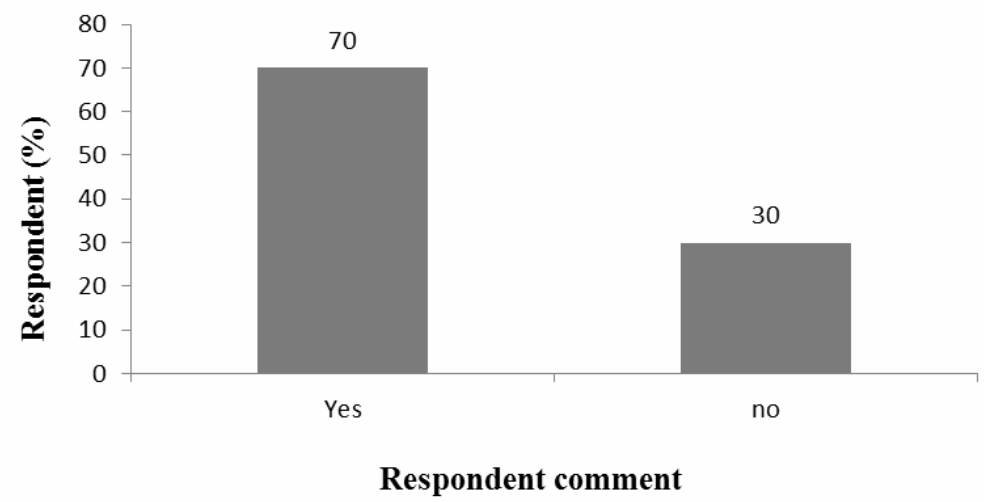

Fig. 2. The percentage of livelihood affected by flood.

Poor households have a greater difficulty in adjusting to a given loss of income than the nonpoor ones. On the other hand, these households are less capable to take protective measures against hazards than rich households. In the community where more than half of the people are 
affected by such hazards it becomes alarming. This also hinders the uplift social, regional and national economy and finally increases poverty.

The Char land people's occupation is largely dependent on the magnitude, frequency and duration of flood. The effect of flood also depends on the type of occupation. The study showed that most of the Char land people are farmers. Due to flood, farmers lose their various crops and thus farming is the most vulnerable occupation. The study showed that $81.81 \%$ farmers were affected by flood (Table 1). As the soil fertility of the Char land is greatly reduced due to siltation after flooding, the productivity of the land becomes lower than the land not affected by flood. A vast amount of agricultural land has been lost into the river due to river bank erosion. Farmers become landless and jobless during the flood. Char land people face difficulty in finding any alternative job at that time. On the other hand, the income of boatmen reduces during the flood than the other periods as they get fewer passengers to carry. Small businessmen face various problems in carrying their goods from one place to another during the flooding period. From the study it was found that 64.70 and $66.7 \%$ of agricultural labors and small businessmen, respectively, were affected by flood. Besides these, 41.66, 28.57 and $42.86 \%$ of fishermen, boatmen and others, respectively, were under threat of flood (Table 1).

Table 1. Relationship between occupation and impact of flood $(n=100)$.

\begin{tabular}{|c|c|c|c|c|c|}
\hline \multirow[t]{2}{*}{ Respondent occupation } & \multicolumn{2}{|c|}{ Impact of flood on livelihood } & \multirow[t]{2}{*}{ Total } & \multicolumn{2}{|c|}{ Percentage } \\
\hline & Yes & No & & Yes & No \\
\hline Fishing & 5 & 7 & 12 & 41.66 & 58.33 \\
\hline Boatman & 2 & 5 & 7 & 28.57 & 71.43 \\
\hline Small business & 4 & 2 & 6 & 66.67 & 33.33 \\
\hline Farmer & 36 & 8 & 44 & 81.81 & 19.19 \\
\hline Agricultural labor & 11 & 6 & 17 & 64.70 & 35.30 \\
\hline Others & 6 & 8 & 14 & 42.86 & 57.14 \\
\hline Total & 64 & 36 & 100 & 64.00 & 36.00 \\
\hline
\end{tabular}

The livelihood of farmers and agricultural labors are directly dependent on the agricultural production. There is also a significant relation between the agricultural production and agricultural wages. Within a particular cropping season, labor demand is high during the period of sowing transplantation and the periods of harvest. In these periods, agricultural wages rise. These periods are interspersed with the relatively slack periods when the crops are left growing in the fields. In these periods, the demand for agricultural workers decline and so do agricultural wages. There are two peak seasons in agricultural wage pattern in Bangladesh. The first continues from mid-April to mid-September and the second continues from mid-November to mid-February. However, in the times of monsoon floods the normal harvest and plantation activities in the fields are disrupted. The floods can occur in the months of June to early October. 
As agricultural production is severely affected by flood, the wages are reduced. The impacts of these floods on the agrarian economy of Bangladesh vary according to the timings of flood surges and extensiveness of the area inundated.

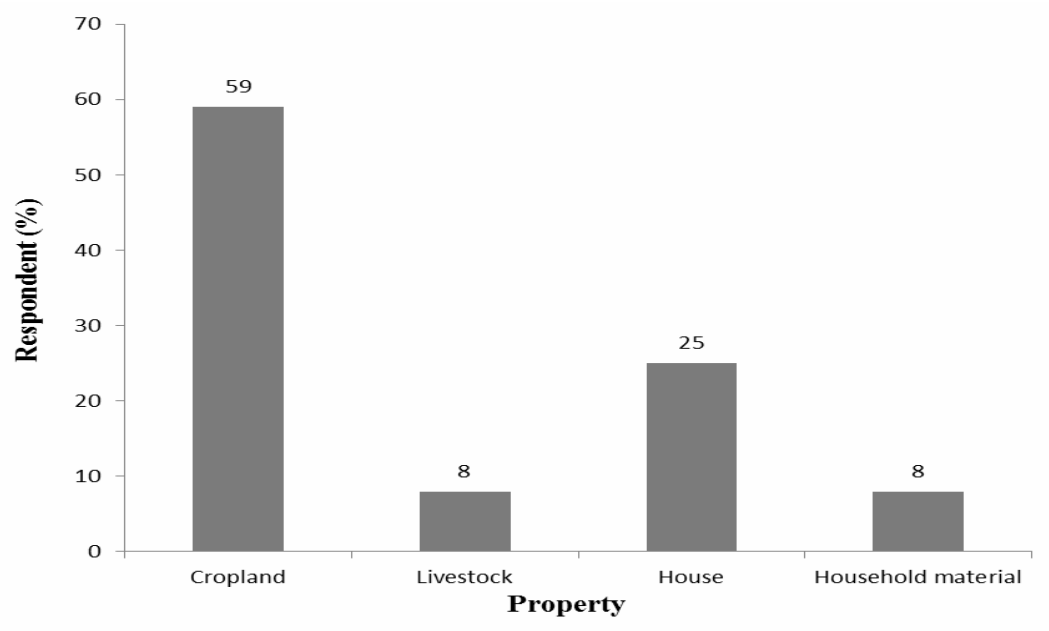

Fig. 3. Properties affected by recent flood.

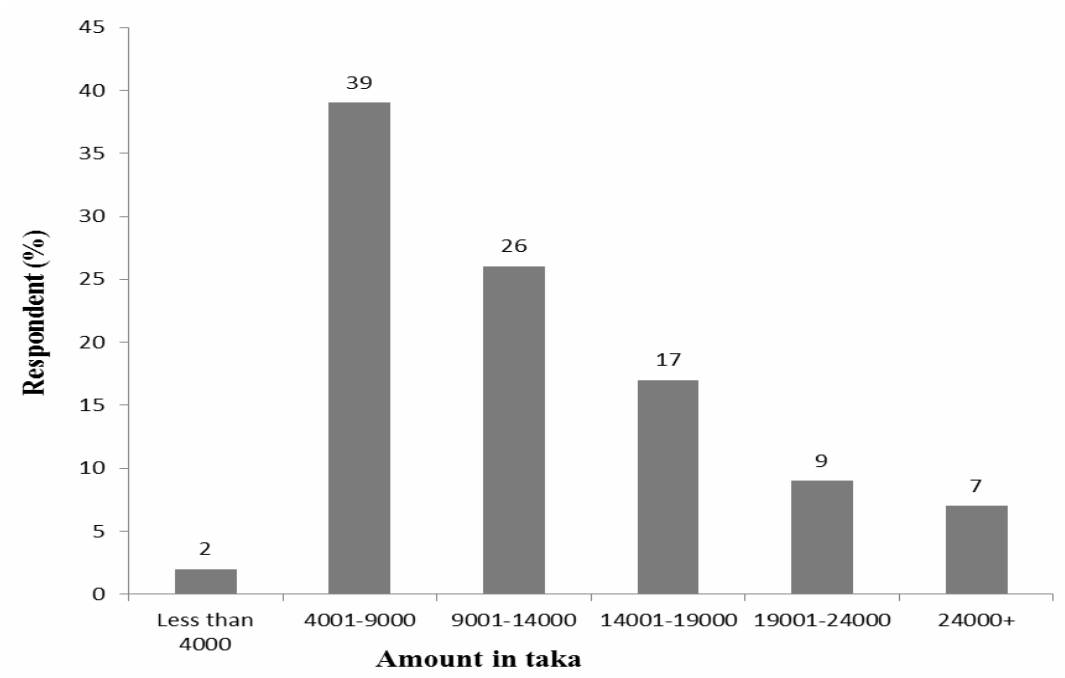

Fig. 4. Financial losses in the recent flood.

Livelihood and property in a community is closely related. When properties are affected it has direct influence on changed livelihoods. The study showed that, in recent flood, 59\% cropland and $8 \%$ livestock are affected by flood water, while $8 \%$ household material and $25 \%$ houses were destroyed (Fig. 3). Along with property losses, every family has some financial losses during the 
flood. Financial losses depend on the frequency and duration of the flood. Average financial loss in recent flood was approximately Tk. 13,000 per family in the study area (Fig. 4).

During the flood, agricultural land is inundated severely which may vary depending on the intensity of flood. When flood occurred for long duration, agricultural lands near to the river lost cropland due to river bank erosion. Siltation during the flood makes agricultural land the more infertile and reduced the productivity of the land. The study found that $86 \%$ agricultural land was adversely affected by flood and only $14 \%$ was not affected (Fig. 5).

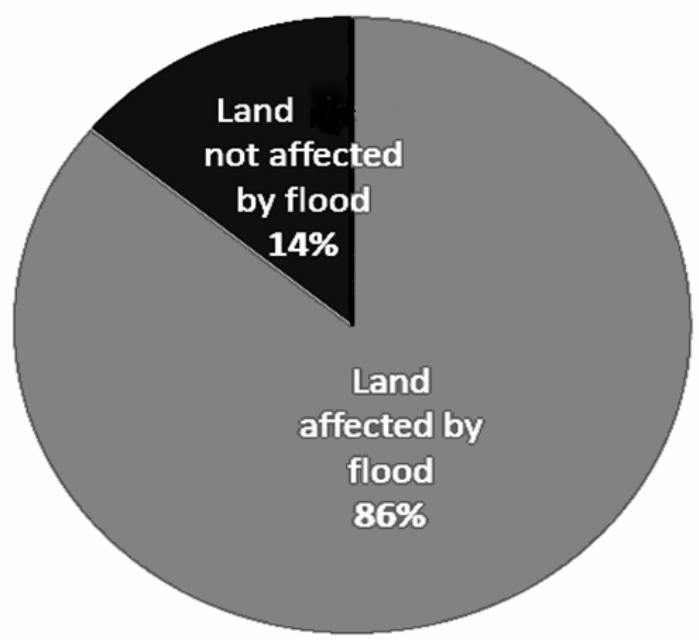

Fig. 5. Agricultural land affected by flood.

The study showed that more than half of the respondents (59\%) get accessibility to secure place during the flood (Fig. 6). In most of the cases, Char land people become shelterless and they stay in the roads, school buildings, in the boat and even on the top of the roof. Char land

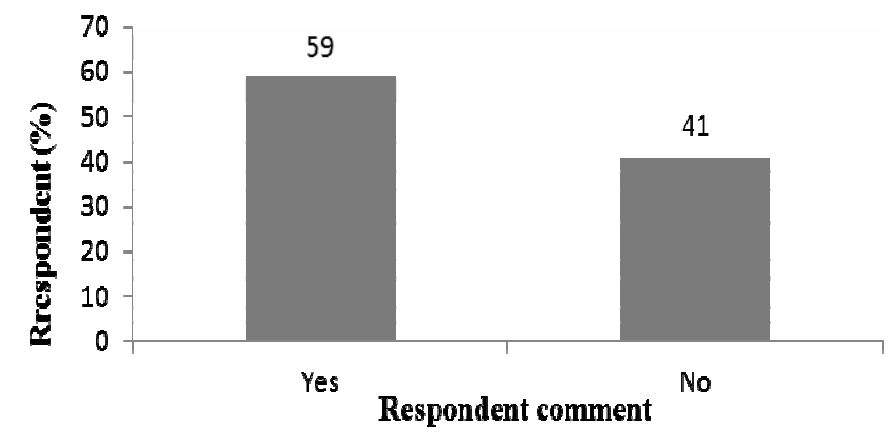

Fig. 6. Accessibility to secure position during the flood.

inhabitants suffered from various water borne diseases such as diarrhea, cholera, typhoid, dysentery, skin diseases, etc. during the flooding period. Some Char land people are often bitten by snakes and water insects. 
Majority of the people in study area have lower income. The monthly income of the respondents in the study area is shown in the Table 2. These lower income people are more vulnerable to the flood than the people who have higher income. The study revealed that there is a significant relationship between people's income and impact of flood on livelihood (Table 2). Poor people fail to maintain minimum life standards during the flood. They cannot afford daily food, medicine and other basic needs.

Table 2. Relationship between monthly income and livelihood impacted by flood.

\begin{tabular}{lcccc}
\hline $\begin{array}{l}\text { Monthly income } \\
\text { (Taka) }\end{array}$ & \multicolumn{2}{c}{ Impact of flood on livilihood } & Frequency & Percentage \\
\cline { 2 - 3 } & Yes & No & & \\
\hline 0 - 2000 & 12 & 4 & 16 & 16 \\
$2001-4000$ & 41 & 20 & 61 & 61 \\
4001 - 6000 & 11 & 10 & 21 & 21 \\
6001 - above & 0 & 02 & 02 & 02 \\
Total & 64 & 36 & 100 & 100 \\
\hline
\end{tabular}

The Char livelihood largely depends on agricultural work and other activities such as farming, fishing, agricultural labor, day labor and business. The study found that food was available to a household engaged in service activities and businessman in Char land people while farmers, laborers, and small vendors had a limited amount of food (Table 3). The study also showed that people take loan during and after a flood which was highest in amount among the laborers and farmers, followed by businessmen and service holders. This is because the laboring class becomes jobless during long-lasting flood and most of them take loan from moneylenders, bank and NGOs at a high rate of interest to make their both ends meet.

Table 3. Occupation of household heads, availability of food and borrowing of money.

\begin{tabular}{|c|c|c|c|c|c|c|c|c|c|c|c|c|c|c|}
\hline \multirow[t]{2}{*}{$\begin{array}{l}\text { Availability } \\
\text { of food }\end{array}$} & \multicolumn{2}{|c|}{ Farmer } & \multicolumn{2}{|c|}{$\begin{array}{l}\text { Agricultural } \\
\text { labor }\end{array}$} & \multicolumn{2}{|c|}{$\begin{array}{l}\text { Fisher- } \\
\text { man }\end{array}$} & \multicolumn{2}{|c|}{ Businessman } & \multicolumn{2}{|c|}{ Boatman } & \multicolumn{2}{|c|}{ Others } & \multicolumn{2}{|c|}{ Total } \\
\hline & $\mathrm{HH}$ & $\%$ & $\mathrm{HH}$ & $\%$ & $\mathrm{HH}$ & $\%$ & $\mathrm{HH}$ & $\%$ & $\mathrm{HH}$ & $\%$ & $\mathrm{HH}$ & $\%$ & $\mathrm{HH}$ & $\%$ \\
\hline Yes & 9 & 20.45 & 4 & 23.52 & 3 & 25 & 4 & 66.67 & 2 & 28.57 & 11 & 78.57 & 33 & 33 \\
\hline No & 35 & 79.55 & 13 & 76.48 & 9 & 75 & 2 & 33.33 & 5 & 71.43 & 3 & 21.43 & 67 & 67 \\
\hline Total & 44 & 100 & 17 & 100 & 12 & 100 & 6 & 100 & 7 & 100 & 14 & 100 & 100 & 100 \\
\hline
\end{tabular}

$\mathrm{HH}=$ Households

Most of the Char land people is farmer, agricultural labor and day labor. Since flood largely affected the agricultural land so that they could not get involved in any work during and after flood. Flood creates a vast crisis in job opportunities. Any alternative occupation is also scarce in 
the study area. The study showed that $87 \%$ people do not find any alternative occupation during flood in the study area, while only 13\% people have alternative occupation (Fig. 7).

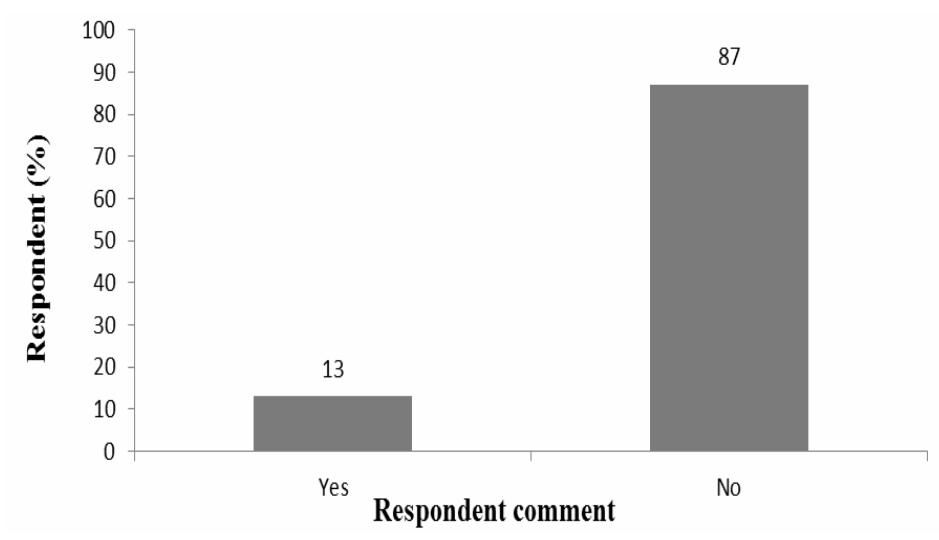

Fig. 7. Scope of alternative occupation.

Rehabilitation program is essential for sustainable livelihood. The study revealed the lack of proper rehabilitation program in the study area. As majority of the Char land people live below the poverty line, they cannot repair or rebuild their houses damaged by the flood. About $84 \%$ of them got no support for rehabilitation, whereas only $16 \%$ people got financial support for rehabilitation (Fig. 8).

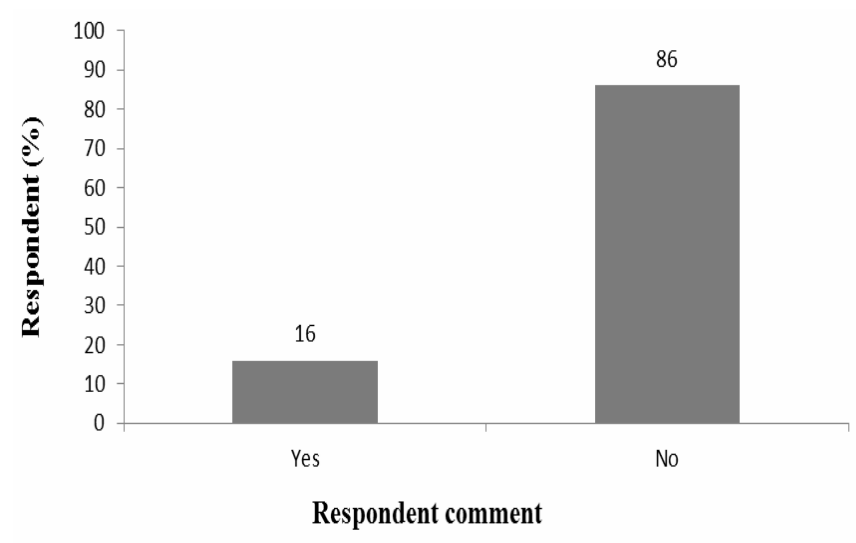

Fig 8. Presence of rehabilitation program in the study area after flood.

People in the study area develop their own adapting techniques to cope with the flooding. Adaptation techniques can be classified as structural or non-structural and indigenous or modern. However, people are used to relying on various indigenous strategies; the adoption of a particular 
set of strategies depends on people's socio-economic circumstances and the characteristics of the flood. People use preventive measures include the placing of barriers around the house and raising the platform of the house. Other measures include using Muchan and Pataton, reducing the number of meals and relying on inexpensive food, depending on relief, taking shelter along road, neighbor house, searching for alternatives sources of income, and selling of land and other assets (Table 4).

Table 4. Adaptation techniques taken by local people for mitigating flood in the study area.

\begin{tabular}{llc}
\hline Adaptation techniques taken for & Adaptation techniques & Respondents (\%) \\
\hline Household items & Using Muchan & 65 \\
& Rising homestead & 20 \\
& Move to safer place & 10 \\
& No measure & 5 \\
\hline Saving shelter & Using water hyacinth barrier & 68 \\
& Rising homestead & 25 \\
& Move to safer place & 4 \\
& No measure & 3 \\
\hline Purification of water & Boiling water & 22 \\
& Purifying tablet & 5 \\
& Use of potassium alum & 3 \\
& No purification & 70 \\
\hline
\end{tabular}

People in study area have adopted different kinds of indigenous strategies to protect crops, including the selection of right type of crop varieties that suit the time frame of floods and the floodwater level as well as the physiographic and soil conditions of the area. The study showed that significant numbers of farmers used to follow the traditional crop calendar of the country. They also use to cultivate mustard, potatoes, pulses, spices, sweet potatoes, vegetables and wheat during the Rabi (post-flood) season. Due to flooding, many farmers prefer sugarcane and jute to paddy as they survive in high floodwater. In the study area, farmers cultivate Boro and other crops during the Rabi season and in the Kharif season; they prefer Jagon to cultivate different vegetables.

The storing of food, fuel and water is a difficult challenge for victims of a flood. People prefer and use big Motki/Kola (made by mud) and polythene bags to stockpile dry food and seed. Households in study area prefer aluminum, earthen and plastic pots to transport fuel and water, as they are easier to carry and normally float. In most houses, the storing place is higher than the normal floor; such places remain safe until there is high floodwater. However, when floodwater increases, people usually prepare a Muchan inside the house and most houses in flood-prone areas have a Pataton that is used to store food, fuel and water. The study showed that majority of the 
respondent (82\%) in the study area use Muchan to protect food, fuel and water (Fig. 9). During high flood people move these things to safer places to mitigate the losses.

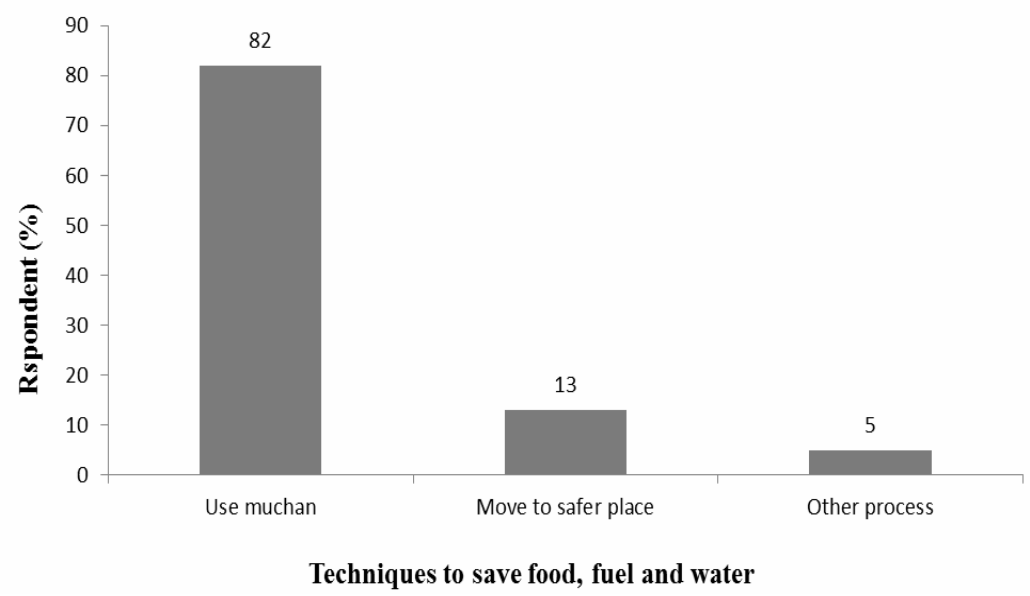

Fig. 9. Adaptation techniques in Char people used to food, fuel and potable water.

As the communication system is not good in the study area, a very few number of NGOs are working for the livelihood restoration. The study found that $92 \%$ of the respondents do not get any financial aid for rehabilitation (Fig. 10).

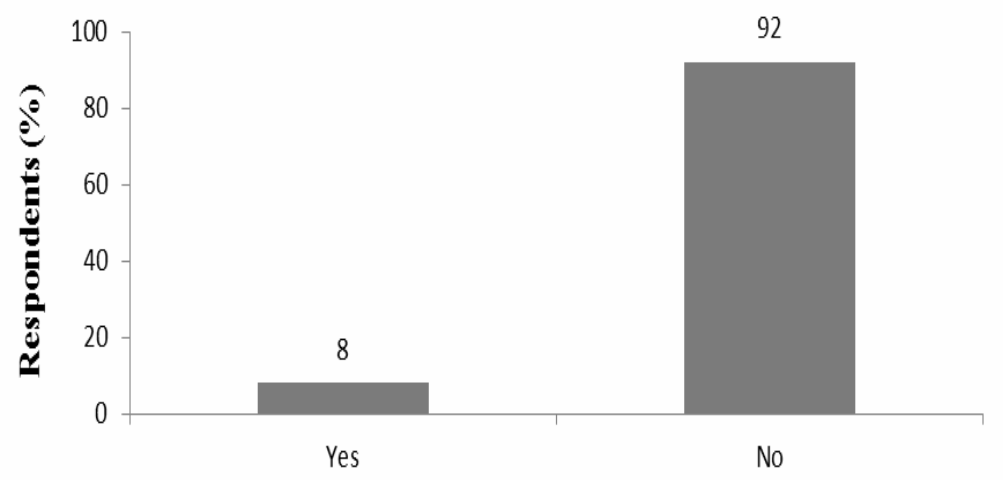

\section{Respondent comment}

Fig. 10. Availability of NGOs working for livelihood restoration after flood.

External assistance, such as a relief programs, has a significant impact on a household's capacity to respond to shock and the timing of relief can play an important role in determining the effectiveness of coping strategies. The study suggested that in addition to food relief, external assistance should include provisions to revive agricultural- and livelihood- related activities as a 
top priority. Food relief is a necessity but providing food-production assistance is more sensible and can enhance victims' ability to cope. The study identified food and drinking water, temporary shelter and access to health services, among other variables, as important needs during a flood; whereas agricultural inputs, employment, food and drinking water and reconstruction of houses are considered vital needs after a flood. Therefore, providing more relief to those who have experienced greater loss can help to create an enabling environment for their coping strategies. If relief is made available early enough and is based on victim's priorities, this may help households to save at least some of their asset base and avoid selling assets or reaching the final stage of destitution.

\section{Conclusions}

Flood is such an environmental issue that can change the environment within a moment. Flood is considered as one of the five major problems in Bangladesh which frequently occurrs almost every year. Many low lying areas of the country are severely affected by flood including the Char land areas. Due to flood various property, household material, crops, livestock, house and many other things are damaged in these areas. During flood, there were lack of available food, drinking water, sanitation and better communication system in the study area. The people of the study area were suffering from various diseases such as typhoid, diarrhea, dysentery, fever and some skin diseases. Thus, their livelihood patterns were completely affected by flood. Among them, farmers were worst affected. During flood, Char people live in extreme condition. Although the annual floods are essential and desirable for overall growth of floodplain and delta plain, as well as for the country, they also create socio-economic, environmental and infrastructural damages. Therefore, people's indigenous adaptation strategies can significantly reduce their vulnerability to disaster if they get proper support from the government and non-governmental organizations.

\section{Acknowledgements}

Sincere thanks to the authority of Ghorjan Union Parishad and Chauhali Upazila Land Office in Sirajgonj, Bangladesh, for their kind cooperation during conducting the study.

\section{References}

Ahmed, R. U. 2001. Impact of bank erosion of the Jamuna River on selected towns in the Northern region of Bangladesh. Ph.D. dissertation, Department of Geography and Environment, Jahangirnagar University, Savar, Dhaka.

Banglapedia. 2008. The national encyclopedia of Bangladesh, The Asiatic Society of Bangladesh, Dhaka.

Blaikie, P., T. Cannon, I. Davis and B. Wisner. 1994. At Risk: Natural Hazards, People’s Vulnerability, and Disasters, Routledge, London.

Brammer, H. 1990. Floods in Bangladesh II: Flood mitigation and environmental aspects. The Geographical Journal 156(2): 158-165. 
Few, R. 2003. Flooding, vulnerability and coping strategies: Local responses to a global threat. Progress in Development Studies 3(1): 43-58.

Handmer, J., E. Penning-Rowsell and S. Tapsell. 1999. Flooding in a warmer world: The view from Europe. In: T. E. Downing, A. A. Olsthoorn and R. S. J. Tol (eds.) Climate, Change and Risk.

Islam, M. S., T. Hasan, M. S. I. R. Chowdhury, M. H. Rahaman and T. R. Tusher. 2012. Coping techniques of local people to flood and river erosion in char areas of Bangladesh. Journal of Environmental Science and Natural Resources 5(2): 251-261.

Milliman, J. D., J. M. Broadus and G. Frank. 1989. Environmental and economic impact of rising sea level and subsiding deltas: The Nile and Bengal examples. In: Bangladesh Quest 1: 11-12.

Paul, B. K. 1984. Perception of and agricultural adjustments to floods in Jamuna floodplain, Bangladesh. Human Ecology 12(1): 1-19.

Paul, B. K. 1997. Flood research in Bangladesh in retrospect and prospect: A review. Geoforum, 28(2): 121131.

Rasid, H. 1993. Preventing flooding or regulating flood levels: Case studies on perception of flood alleviation in Bangladesh. Natural Hazard 8(1): 39-57.

Smith, K. 1996. Environmental Hazards: Assessing Risk and Reducing Disaster, Routledge, London.

UNEP (United Nations Environment Program). 2001. Bangladesh: State of the Environment 2001, United Nations Environment Program (UNEP).

(Manuscript received on August 23, 2015; revised on December 15, 2015) 